\title{
Pembelajaran Group Investigation dan Talking Chips untuk Meningkatkan Aktivitas dan Hasil Belajar
}

\author{
Moh. Farid Nurul Anwar, Kardiana Metha Rozhana* \\ Universitas Tribhuwana Tunggadewi, Indonesia \\ anwarmohfaridnurul@gmail.com*
}

\begin{abstract}
Conventional learning models are less effective for use in the 2013 curriculum which emphasizes scientific approaches. Innovative learning models are needed for learning in the 2013 curriculum. One form of innovative learning models is the Gl learning model. The purpose of the research is to describe the application of Gl learning models and Talking Chips methods to improve student learning outcomes and activities. This type of research is used by CAR, with four steps including planning, treatment and observation, reflection. While the techniques for obtaining data through observation, tests, interviews, and documentation. Learning outcomes cycle 1 gained a score of 84 to 89 and cycle 2 a score of 92 to 96.
\end{abstract}

Key Words: Gl; talking chips; learning (activity,outcome)

\begin{abstract}
Abstrak: Model pembelajaran konvensional kurang efektif untuk digunakan pada kurikulum 2013 yang menekankan pada pendekatan scientific. Model pembelajaran inovatif diperlukan untuk pembelajaran pada kurikulum 2013. Salah satu bentuk model pembelajaran inovatif adalah model pembelajaran GI. Tujuan penelitian yaitu mendeskripsikan penerapan model pembelajaran GI dan metode Talking Chips untuk meningkatkan hasil dan aktivitas belajar siswa. Jenis penelitian yang digunakan PTK, dengan empat langkah diantaranya planning, treatment and observation, reflection. Sedangkan teknik untuk memperoleh data melalui observasi, tes, wawancara, serta dokumentasi. Hasil belajar siklus 1 memperoleh skor 84 menjadi 89 serta siklus 2 skor 92 menjadi 96.
\end{abstract}

Kata kunci: Gl; talking chips; aktivitas; hasil belajar

\section{Pendahuluan}

Kelas merupakan tempat dalam proses, aktivitas, serta untuk mencapai pembelajaran. Beberapa faktor dapat mempengaruhi kualitas pembelajaran di kelas, antara lain yang berkaitan dengan siswa secara individu (seperti kinerja pembelajaran dan harapan untuk hasil belajar), yang berkaitan dengan pengajaran di kelas (misalnya, kejelasan pengajaran, kecukupan materi pelajaran, dan metode pembelajaran), serta guru (misalnya, kompetensi dan antusiasme pengajar). Guru merupakan pembuat kreatifitas dikelas sehingga dapat menghidupkan suasana kelas (Rozhana, 2019). Salah satu hal terpenting untuk mencapai hasil belajar siswa yaitu melalui metode pembelajaran. Hasil wawancara dan observasi diperoleh data bahwa pembelajaran masih menggunakan metode konvensional sehingga kurang efektif pada kurikulum 2013 yang menekankan pendekatan scientific dan proses (Rozhana, 2017). Dapat dikatakan bahwasannyaa untuk mencapai pembelajaran yang sesuai 
dengan tujuan pembelajran yang dapat mengaktifkan siswa dan hasil belajar meningkat melalui metode pembelajaran.

Menurut (Pranata, 2016) Pembelajaran menggunakan Group Investigation melibatkan siswa dalam setiap kegiatan (memilih topik, kooperatif dalam perencanaan, mengimplementasikan, menganalisis \& sintesis, mempresentasikan hasil kinerja, dan mengevaluasi. Sedangkan menurut (Christina \& Kristin, 2016) aspek afektif diperoleh dari dialog/berbicara antar teman sehingga menciptakan pembelajaran dengan model Group Investigation. Sikap sosial dapat dipupuk dalam menentukan topik bersama teman sejawat dan guru. Kemudian siswa akan berinteraksi dengan kelompok untuk menginvestigasi topik dan mencari solusi bersama teman kelompok, mempresentasikan, dan berdiskusi dengan kelompok lain dengan seperti itu akan menumbuhkan sikap sosial antar siswa lainnya (Sai, 2017).

Talking Chips yaitu teknik dalam pembelajaran dengan memanfaatkan benda kecil yang memiliki fungsi sebagai alat untuk memulai pembicaraan atau aktivitas belajar (Yanda, 2013). Sedangkan menurut (Widyaningrum \& Prihastari, 2018) Talking Chips merupakan pembelajaran yang memberikan kontribusi pada masing-masing kelompok untuk mendegarkan pandangan.pemikiran kelompok serta adanya peningkatan diskusi. Sedangkan menurut (Suprapti, 2016) Talking Chips merupakan pembelajaran yang memanfaatkan Chips dalam menyatakan pendapat, bertanya, menjawab, atau memberikan gagasan lain.

Penelitian yang relevan dengan penelitian ini adalah penelitian yang dilakukan oleh Simanjuntak and Siregar (2014), model Group Investigation berpengaruh terhadap hasil belajar siswa. Menurut Hariyanto, Asto, and Putu (2015) metode pembelajaran talking chips memiliki pengaruh terhadap hasil belajar. Penelitian ini memiliki perbedaan dengan penelitian sebelumnya. Perbedaan penelitian ini dari penelitian terdahulu yakni pada penelitian ini mengkombinasi model Group Investigation dengan metode talking chips. Novelty penelitian ini adalah peneliti menggunakan kombinasi model Group Investigation dan metode talking chips untuk meningkatkan aktivitas dan hasil belajar siswa. Oleh karena itu, tujuan dari penelitian yaitu menerapkan model pembelajaran GI dengan metode Talking Chips untuk meningkatkan hasil belajar dan aktivitas siswa.

\section{Metode}

Penelitian Tindakan Kelas (PTK) merupakan metode yang digunakan dengan mengunakan alur PTK model Kemmis dan Taggart yaitu terdapat 3 tahap yaitu perencanaan, perlakuan dan pengamatan, serta refleksi (Arikunto, 2010). Kehadiran serta peran peneliti yaitu sebagai perencana, pelaksana, pengamat, pengumpul data, analisis data, serta menyusun laporan penelitian. Penelitian dilakukan di SDN Merjosari 1 Kelas IV dengan jumlah 30 siswa di Jalan Joyo Utomo No 2 Kecamatan Lowokwaru Kota Malang Jawa Timur 65144. Penelitian dilakukan selama bulan Desember 2019 - Maret 2020 dengan subjek siswa kelas IV.

Data penelitian berupa data observasi, tes hasil belajar, unjuk kerja, dan wawancara. Tes observasi dilakukan untuk mengetahui aktivitas belajar, tes hasil belajar mengetahui 
kognitif, unjuk kerja untuk mengetahui hasil dari sikap psikomotorik, dan aspek afektif melalui observasi selama penelitian berlangsung. Selanjutnya, data hasil wawancara guru kelas IV (Pengamat 1) terkait penerapan pembelajaran Group Investigation dan Talking Chips pada pembelajaran tematik untuk penilaian metode yang digunakan.

Analisis data yang terdiri dari (reduksi data, penyajian data, dan pengambilan kesimpulan) (Suratmi: 2018). Reduksi data merupakan langkah pemilihan dan pemusatan perhatian serta perubahan data kasar selama catatan di lapangan antara lain: (1) Data observasi (pengamat merupakan guru kelas dengan lembar APKG sebagai acuan), observasi aktivitas selama proses pembelajaran baik afektif maupun psikomotorik dilakukan oleh guru (pengamat 2). (2) Data hasil tes berupa evaluasi akhir pembelajaran dari berbagai muatan. Sedangkan penyajikan data berupa ringkasan terstruktur, deskripsi singkat, diagramdiagram dan matrik. Penyimpulan merupakan tahap penyimpulan dari menjawab permasalahan dan menjawab masalah sehingga perlu dilakukan siklus 2 atau tidak.

Prosedur Penelitian dilakukan dengan tiga tahap yaitu perencanaan terdiri dari siklus-1 (a) observasi awal, (b) menetapkan dan merumuskan rancangn tindakan (perlakuan dan pengamatan, serta refleksi). Selanjutnya siklus lanjutan yaitu hasil dari refleksi siklus 1 berupa perbaikan tindakan yang bertujuan untuk peningkatan hasil belajar maupun aktivitas melalui pemberian metode siklus 2 .

\section{Hasil dan Pembahasan}

Pelaksanaan siklus 1 dan siklus 2 dilaksanakan berdasarkan komponen pembelajaran yang telah disusun secara sistematis agar tujuan pembelajaran tercapai. Komponen pembelajaran yang disusun dengan matang akanmendapatkan hasil yang optimal. Keberhasilan siklus 1 \& siklus 2 tidak cukup hanya mengandalkan nilai hasil belajar siswa. Implementasi pembelajaran siklus 1 maupun siklus 2 berjalan dengan baik. Hasil pengamat 1 melalui lembar observasi alat penilaian desain pembelajaran atau disingkat APDP dan alat penilaian kemampuan mengajar (APKM). Hasil pengamatan yaitu pada siklus 1 APDP diperoleh skor 90 serta meningkat dengan skor 98 pada siklus 2, sedangkan APKM memperoleh skor 97 pada siklus 1 dan siklus 2. Dengan demikian, pelaksanaan model pembelajaran Group Investigation dan Talking Chips pada tema 7 Indahnya Keragaman di Negeriku pada sub tema keragaman suku bangsa dan agama di Negeriku, pembelajaran satu (siklus 1) dan 2 (siklus 2) sangat baik.

Rencana pelaksanaan pembelajaran disesuaikan antara meteri dengan model pembelajaran yaitu Group Investigasi dan Talking Chips. Siswa dibagi menjadi 6 kelompok untuk menginvestigasi materi tentang keragaman suku bangsa dan macam-macam gaya. Pada siklus 1 terdapat terdapat dua muatan pelajaran yang harus siswa kuasai yaitu Bahada Indonesia dam IPA. Pada muatan bahasa Indonesia yaitu siswa diharapkan mampu menggali dan menyampaikan informasi baru, sedangkan muatan IPA yaitu siswa diharapkan mampu menjelaskan macam-macam gaya. Subtema pada pembelajaran 1 ini yaitu keberagaman Suku Bangsa dan Agam. Masing-masing kelompok telah dibagikan tugas menginvestigasi 6 suku sesuai jumlah kelompok dan 6 dengan materi antara lain : suku Jawa, Madura, 
Tengger, Oseng, Bali dan Papua sengakan jenis gaya yaitu: otot, pegas, gesek, gravitasi, magnet, listrik. Artinya satu kelompok mendapatkan tugas investigas yaitu suku dan gaya.

Siklus 2 terdapat 3 muatan (Bahasa Indonesia, IPA, dan SBdP). Untuk materi BI dan IPA cendeung sama hanya bentuknya memperdalam dari siklus 1 sedangkan SBdP yaitu tentang tinggi rendah nada. Sehingga kelompok tetap dibagi menjadi 6 kelompok dan anggotanya sama. Materi BI yaitu mencari lagu daerah sesuai Suku yang dicari pada siklus 1, untuk materi SBdP yaitu menyanyikannya 1 lagu secara bersama sesuai tinggi rendahnya nada serta menceritakan sejarah lagu itu dan mkna yang trkandung, dan materi IPA yaitu menceritakan dan mendemontrasikan manfaat gaya yang telah di bahas pada siklus 1.

Pembelajaran Group Investigasi digabung dengan model Talking Chips yaitu siswa diberi satu kelereng dan setiap kelompok mendapat kotak kelereng. Setiap siswa yang bertanya atau menjawab mereka akan meletakkan kelereng tersebut pada kotak yang terdapat di meja masing-masing, sehingga tidak hanya siswa yang aktif dalam bertanya melainkan siswa lain juga memiliki kesempatan yang sama. Talking Chips merupakan teknik dalam menilai aspek berbicara dimana setiap siswa memiliki kesempatan yang sama. Langkah-langkah Talking Chips menurut (Kemdikbud (2013)) sebagai berikut: (1) menyiapkan sejenis benda (bisa benda-benda didalam kelas), (2) menekankan pada aspek berbicara, (3) memeberikan kesempatana kelompok untuk berbicara, (4) jika kelompok memiliki tugas yang belum selesai dapat diberikan kesempatan lagi.

Hasil wawancara siklus 1 oleh pengamat 1 menyatakan bahwa terdapat kelebihan dan kelemahan pada proses siklus 1. Pada model ini memberikan semua siswa untuk aktif bertanya dan menjawab. Namun, terdapat kelemahan yaitu siswa memiliki kesempatan bertanya dan menjawab satu kali karena diberikan satu kelereng sehigga membatasi siswa untuk bertanya atau menjawab. Saran dari pengamat yaitu nemambahkan jumlah kelereng mengingat sebagian besar siswa justru antusias untuk bertanya.

Masukan dari pengamat 1 diterapkan pada siklus 2, yaitu masing-masing siswa diberikan dua kelereng dengan mempertimbangkan waktu pembelajaran. Siklus 2 berjalan tidak jauh berbeda dengan siklus 1 , siswa mengikuti pembelajaran. Setiap kelompok yang mempresentasikan hasil ivestigasinya, semua kelereng diletakkan di kotak kelereng pada meja kelompok masing-masing. Kondisi seperti itu menandakan semua siswa aktif bertanya dan menjawab dalam kegiatan pembelajaran. Berikut merupakan langkah pembelajaran.

Tabel 1. Langkah Kegiatan Group Investigation dan Talking Chips

\begin{tabular}{lll}
\hline a. Memilih Topik $\quad$ : Menentukan topik pembahasan pada Tema 7 Indahnya Keragaman di Negeriku Subtema 1 \\
& Keragaman Suku Bangsa dan Agama di Negeriku, pembelajaran 1 dan 2. Selanjutnya siswa \\
& dikelompokkan menjadi 6 menjadi kelompok-kelompok bagian yang berorientasi pada tugas yang \\
& diberikan guru. Topik yang dipilih berdasarkan keberagaman Suku Bangsa dan Agam. Terdapat 6 \\
& kelompok membahas keragaman suku, dan macam-macam gaya) \\
& : Siswa bersama guru bersama-sama merencanakn prosedur dan tugas pembelajaran dan tujuan \\
b. Perencanaan & khusus topik yang dipilih pada subtema 1 pembelajaran 1 dan 2. Dimana pembelajaran 1 \\
& kelompok mencari tahu tentang 6 suku yaitu, jawa, Madura,tengger, osing, papua, bali, dan 6 \\
& macam gaya yaitu: otot, pegas, gesek, gravitasi, magnet, listrik. \\
& : siswa menginvestigasi tugas yang diberikan, Siswa melaksanakan pembelajaran dengan \\
& memperhatikan aktivitas dan keterampilan dengan menggunakan beberapa sumber belajar yang \\
& kongkrit.
\end{tabular}




\begin{tabular}{|c|c|c|}
\hline d. & $\begin{array}{l}\text { Analisis } \\
\text { Sintesis }\end{array}$ & $\begin{array}{l}\text { : Menganalisis, mensintesis informasi dan merencanakan menyajikan informasi yang sudah } \\
\text { diringkas dan dapat mempresentasikan. }\end{array}$ \\
\hline e. & $\begin{array}{l}\text { Presentasi Hasil } \\
\text { Akhir }\end{array}$ & $\begin{array}{l}\text { : Secara berkelompok siswa mempresentasikan dan menyajikan hasil } \\
\text { melibatkan kelompok lain untuk menghasilkan perpektif topik lain. }\end{array}$ \\
\hline f. & Evaluasi & : Siswa bersama guru mengevaluasi hasil kerja secara menyeluruh. \\
\hline
\end{tabular}

Aktivitas pembelajaran berjalan dengan baik hal ini dapat terlihat saat dilaksanakan observasi oleh pengamat. Beberapa hal yang diperoleh melalui pengamatan yaitu siswa mau bertanya menjawab sehingga aktivitas pembelajaran sudah terlihat (Student Centered Learning) hal ini sesuai dengan pernyataan (Machin, 2012) aktivitas pembelajaran diukur melalui beberapa kinerja baik kelompok maupun individu serta kemampuan siswa menjawab, membangun ide, memanfaatkan waktu, dan responsif.

Hasil observasi/pengamatan aktivitas belajar siswa siklus 1 dari 30 siswa semua aktif bertanya dengan intensitas pertanyaan hanya satu pertanyaan saja karena dibatasi oleh jumlah satu kelereng pada setiap siswa. Sedangkan siklus 2 semua siswa bertanya dan menjawab dengan intensitas, setiap siswa aktif bertanya dan menjawab sebanyak dua pertanyaan. Hal ini, dilihat jumlah kelereng diakhir diskusi pada kotak kelereng terisi penuh. Pembatasan dua kelereng dikarenakan alokasi waktu pembelajaran.

Pembelajaran Group Investigation dan Talking Chips siswa yang bertanya cenderung yang pintar saja, dari 30 siswa hanya 6 orang saja yang aktif bertanya yaitu sekitar $20 \%$ saja yang aktif. sehingga kesempatan siswa yang lain untuk bertanya dirasa kurang. Pembelajaran Group Investigation dan Talking Chips dapat mengaktifkan belajar, menyampaikan pendapat dengan menunjukkan $100 \%$ aktif dalam pembelajaran (aspek bertanya).

Hasil belajar merupakan tujuan dari pembelajaran yang diukur melalui aspek kognitif, afektif, dan psikomotorik (Kemendikbud, 2013) melalui K13 penialain ditekankan pada nilai proses dengan pendekatan scientifik baik proses, sikap, kognitif, dan skill/keterampilan. Penilaian digunakan melalui beberapa tahap yaitu sikap (observasi, penilaian siswa, dan teman sejawat, serta jurnal/hasil kinerja), kognitif ( tes tulis, lisan, presentasi, penugasan), serta keterampilan (kinerja, demonstrasi, praktek, projek, portofolio).

Penilaian aspek afektif dibagi menjadi 2 diantaranya: (1) penialain sikap spiritual yang dilakukan siswa yaitu berdoa sebelum dan sesudah pembelajaran pada siklus 1 \& siklus 2; dan (2) sikap sosial yaitu siswa bersalaman kepada guru pagi dan ketika hendak pulang dari sekolah. Selain itu, siswa secara bergantian bertanya dan menjawab dalam diskusi. Keseriusan dalam mempresentasikan hasil investigasi dan kejujuran dalam menaruh kelereng ini berkaitan dengan siswa sudah bertanya atau tidak. Semua yang dilakukan siswa diamati oleh pengamat dan guru.

Penilaian pengetahuan yaitu terdapat lembar kerja kelompok (untuk menginvestigasi) dan lembar evaluasi diakhir pembelajaran. Hasil siklus 1 rerata siswa memperoleh skor 84 sedangkan siklus 2 memperoleh skor 92 . Nilai ini merupakan nilai harian sehingga nilai berupa angka atau skor. Aktivitas belajar dinilai melalui lembar aktivitas belajar siswa. Aspek yang dinilai yaitu kelompok dan individual. Aktivitas kelompok yaitu mempresentasikan hasil investigasi tugas kelompok dan individu yaitu keaktifan dalam bertanya pada setiap presentasi 
kelompok yang tampil. Pada siklus 1diperoleh skor $89 \%$ dan siklus $296 \%$ siswa aktif bertanya dan menjawab.

\section{Kesimpulan}

Hasil dari penelitian di SDN Merjosari 1 Malang diperoleh kesimpulan bahwa pembelajaran Gl dan Talking Chips meningkatkan hasil dan aktivitas belajar. Penerapan pembelajaran $\mathrm{Gl}$ dan Talking Chips berhasil dengan tingkat keberhasilan sangat baik. Hasil Belajar Siklus 1 yaitu 84 dan pada siklus 2 mendapatkan skor 92. Sedangkan aktivitas belajar siklus 1 yaitu 89 \% siswa aktif dan siklus 2 sebanyak 96\% siswa aktif. Berdasarkan hal tersebut dapat dikatakan ba hwa penggunaan dua model pembelajaran tersebut efektif digunakan dalam proses pembelajaran. Namun, harus diperhatikan karakteristik lingkungan belajar siswa.

\section{Daftar Rujukan}

Arikunto, S. (2010). Prosedur Penelitian Suatu Pendekatan Praktik. Jakarta: Rineka Cipta.

Christina, L. V., \& Kristin, F. (2016). Efektivitas Model Pembelajaran Tipe Group Investigation (Gi) Dan Cooperative Integrated Reading And Composition (Circ) Dalam Meningkatkan Kreativitas Berpikir Kritis Dan Hasil Belajar Ips Siswa Kelas 4. Scholaria: Jurnal Pendidikan Dan Kebudayaan. https://doi.org/10.24246/j.scholaria.2016.v6.i3.p217230

Hariyanto, Yacob, Asto, B, \& Putu, I Gusti. (2015). Pengaruh metode pembelajaran tipe talking chips terhadap hasil belajar siswa pada kompetensi dasar memahami model atom bahan semi konduktor di SMK Negeri 1 Jetis Mojokerto. Jurnal Pendidikan Teknik Elektro, 4(3).

Kemdikbud. (2013). Panduan Teknis Penilaian di Sekolah Dasar (Vol. 2). Jakarta: Direktorat jenderal Pendidikan Dasar RI.

Machin, A. (2012). Pengaruh permainan call cards terhadap hasil belajar dan aktivitas pembelajaran biologi. Jurnal Pendidikan IPA Indonesia. https://doi.org/10.15294/jpii.v1i2.2134

Muklas, M. (2017). Talkihips Technique To Teach Speaking. Channing, 2(1), 58-64.

Pranata, E. (2016). Implementasi Model Pembelajaran Group Investigation (GI) Berbantuan Alat Peraga Untuk Meningkatkan Kemampuan Pemahaman Konsep Matematika. JPMI (Jurnal Pendidikan Matematika Indonesia). https://doi.org/10.26737/.jpmi.v1i1.80

Rozhana, K. M. (2017). Model Problem Based Intruction Berbantuan Mind Mapping Pada Materi Permasalahan Sosial Di Lingkungan Setempat Untuk Meningkatkan Aktivitas Dan Hasil Belajar Siswa Kelas IV SD. Jurnal Pendidikan Dasar Nusantara.

Rozhana, K. M. (2019). Pengembangan Modul Berbasis Daerah Trenggalek Untuk Menumbuhkan Sikap Peduli Lingkungan. Jurnal Bidang Pendidikan Dasar. https://doi.org/10.21067/jbpd.v3i2.3295

Sai, M. (2017). Pengaruh model group investigation berbasis internet terhadap hasil belajar dan kemampuan digital literasi siswa. Harmoni Sosial: Jurnal Pendidikan IPS. https://doi.org/10.21831/hsjpi.v4i1.9869

Simanjuntak, Salomo Leonardus, \& Siregar, Nurdin. (2014). Pengaruh Model Pembelejaran Kooperatif Tipe Group Investigation terhadap Hasil Belajar pada Materi Listrik Dinamis. INPAFI (Inovasi Pembelajaran Fisika), 2(2). 
Suprapti, L. (2016). Upaya Meningkatkan Hasil Belajar Pkn Materi Globalisasi Melalui Model Pembelajaran Kooperatif Tipe Talking Chips. Briliant: Jurnal Riset Dan Konseptual. https://doi.org/10.28926/briliant.v1i1.3

Widyaningrum, R., \& Prihastari, E. B. (2018). Implementasi Model Pembelajaran Talking Chips Disertai Media Fotonovela Untuk Meningkatkan Sikap Peduli Lingkungan Dan Kemampuan Menyampaikan Pendapat Mahasiswa. Premiere Educandum: Jurnal Pendidikan Dasar Dan Pembelajaran. https://doi.org/10.25273/pe.v8i1.2033

Yanda, A. B. (2013). Pengaruh Peggunaan Teknik Talking Chip Terhadap Hasil Belajar Ipa Fisika Siswa Kelas Vii Smpn 1 Iv Jurai Kabupaten Pesisir Selatan. Pillar of physics education. https://doi.org/10.24036/497171074 